\title{
EVALUATION OF CARCINO EMBRYONIC ANTIGEN (CEA) AND CARBOHYDRATE ANTIGEN (CA19-9) IN MONITORING OF TREATMENT RESPONSE IN GASTROINTESTINAL CANCERS
}

\author{
Rosemary Vumkhoching1, Yengkhom Sanatomba Singh2, Dhanabir Thangjam³, Ningombam Jitendra ${ }^{4}$
}

${ }_{1}^{1}$ Associate Professor, Department of General Surgery, Jawaharlal Nehru Institute of Medical Sciences (JNIMS), Porompat, Imphal, Manipur, India.

${ }^{2}$ Assistant Professor, Department of General Surgery, Jawaharlal Nehru Institute of Medical Sciences (JNIMS), Porompat, Imphal, Manipur, India.

${ }^{3}$ Senior Resident, Department of General Surgery, Jawaharlal Nehru Institute of Medical Sciences (JNIMS), Porompat, Imphal, Manipur, India.

${ }^{4}$ Professor, Department of General Surgery, Jawaharlal Nehru Institute of Medical Sciences (JNIMS), Porompat, Imphal, Manipur, India. ABSTRACT

\section{BACKGROUND}

Carcino Embryonic Antigen (CEA) and Carbohydrate Antigen 19-9 (CA 19-9) were two tumour markers frequently used in the diagnosis, and monitoring of treatment response of gastrointestinal cancers like colon, rectum, stomach, pancreas and gall bladder cancers.

\section{MATERIALS AND METHODS}

This study is a case-control study. 50 diagnosed and confirmed cases of gastrointestinal cancers attending the surgery outpatients department and wards of Jawaharlal Nehru Institute of Medical Sciences, Imphal, Manipur, India from March 2015 to February 2018 form the study group. CEA and CA19-9 estimation was done before the start of any treatment, during treatment and after treatment; may it be Surgery, Radiotherapy or Chemotherapy. The usefulness of these two tumour markers, CEA and CA19-9 combined for monitoring the treatment response was evaluated.

\section{RESULTS}

It is found that the combined use of these two markers CEA and CA19-9 is much more useful for monitoring of treatment response in the patients of gastrointestinal cancers when compared to the use of CEA alone or CA19-9 alone.

\section{CONCLUSION}

It is found that the combined use of these two markers CEA and CA19-9 is much more useful for monitoring of treatment response in the patients of gastrointestinal cancers when compared to the use of CEA alone or CA19-9 alone.

\section{KEY WORDS}

CEA (Carcino Embryonic Antigen), CA19-9 (Carbohydrate Antigen 19-9), Gastrointestinal Cancers, Treatment Response, Radiotherapy, Chemotherapy.

HOW TO CITE THIS ARTICLE: Vumkhoching R, Singh YS, Thangjam D, et al. Evaluation of carcino embryonic antigen (CEA) and carbohydrate antigen (CA19-9) in monitoring of treatment response in gastrointestinal cancers. J. Evolution Med. Dent. Sci. 2018;7(51):5466-5469, DOI: 10.14260/jemds/2018/1209

\section{BACKGROUND}

The magnitude of cancer problem is enormous. Cancer accounts for $12 \%$ of all deaths throughout the world. In developed countries cancer is the second leading cause of death amounting to $21 \%$ of all mortality. In developing countries, cancer ranks third as the cause of death and accounts for $9.5 \%$ of all deaths. In India alone, over 5 lakh new cases of cancer and 3 lakh deaths were estimated every year. Among the cancer deaths, those of the gastrointestinal tract like oesophagus, stomach, colon, rectum, pancreas, gall

'Financial or Other Competing Interest': None.

Submission 05-09-2018, Peer Review 04-12-2018,

Acceptance 10-12-2018, Published 17-12-2018.

Corresponding Author:

Dr. Yengkhom Sanatomba Singh,

Assistant Professor,

Department of General Surgery,

Jawaharlal Nehru Institute of Medical Sciences (JNIMS),

Porompat, Imphal,

Manipur, India.

E-mail: yengkhomsanatomba@gmail.com

DOI: $10.14260 /$ jemds/2018/1209

\section{(c) $($ () $\$$}

bladder etc. occupy the second place, only to be preceded by lung cancer (Park K 2000). ${ }^{1}$

Tumour markers may be used as a means of monitoring treatment in patients in whom there is difficulty to assess response to chemotherapy in clinical practice (Yamao $\mathrm{T}$ et al 1999).2

With the discovery of Carcino Embryonic Antigen(CEA), an onco foetal antigen in colorectal cancer in 1965 by Gold $P$ and Friedman SO, ${ }^{3}$ a new era of tumour marker investigation and application emerged (Sherret GV 1982). ${ }^{4}$

CEA is an intracellular protein normally found in low concentration in embryonic and foetal gut, pancreas and liver cells. Normal CEA levels in plasma were usually determined to be less than $5 \mathrm{ng} / \mathrm{ml}$ in normal healthy individuals. It may be elevated in smokers and in some malignant and benign diseases of the gastrointestinal tract e.g. cirrhosis of liver, pancreatitis and ulcerative colitis (Wiratkapun $S$ et al 2001). ${ }^{5}$

Carbohydrate Antigen 19-9 (CA 19-9) is another tumour marker frequently used for diagnosis and to monitor response to treatment in gastrointestinal cancers (Posner MR and Mayer RJ 1994). ${ }^{6}$ Koprowski et al7 in 1979 first identified it and is the first tumour marker of the group of new epitopes including CA 125 and CEA defined by monoclonal antibodies. 
CA 19-9 level in healthy individual has been established to be less than $37 \mathrm{U} / \mathrm{ml}$ (Posner MR and Mayer RJ 1994). ${ }^{6}$

Serum CA19-9 concentration not only is highly and frequently elevated in both gastric and pancreatic cells but is also useful for monitoring the success of therapy and detecting recurrence in cancer patients. The lead time from CA19-9 elevation to clinical recurrence is one to several months (James TW 1996). ${ }^{8}$

CEA and CA19-9 were now widely utilized as markers for both the primary diagnosis and post treatment monitoring of patients with colorectal cancer (Ueda T et al 1994). ${ }^{9}$

\section{Objective}

\section{The objectives of our study are as follows}

1. To measure the serum values of Carcino Embryonic Antigen (CEA) and Carbohydrate Antigen 19-9 (CA 19-9) in diagnosed cases of primary gastrointestinal cancer patients attending the Department of Surgery, Jawaharlal Nehru Institute of Medical Sciences, Imphal and to compare with that of normal individuals (Control group)

2. To assess the roles of CEA and CA 19-9 as a tool for diagnosis and monitoring of treatment response in gastrointestinal cancers.

\section{MATERIALS AND METHODS}

This study is a case-control study, which was carried out in the wards and Out Patient Department, Department of Surgery, Jawaharlal Nehru Institute of Medical Sciences, Imphal.

A total of 200 sample of were enrolled and divided into 100 cases in the study group and 100 cases in the control group. Out 100 study group, only 50 cases completed the follow up and were included for the analysis. And whereas we selected the control group with 50 cases randomly from the healthy and free from cancer of any part of the body so to have a matching sample size. The study was conducted from March 2015 to February 2018 (2 years and 11 months)

For the study group S.CEA and S.CA19-9 level estimation were done before the start of any treatment, during treatment and after treatment; may it be Surgery, Radiotherapy or Chemotherapy. And for the control group both serum tumour marker levels were measured only once at the time of enrolment. The usefulness of these two tumour markers, CEA and CA19-9 combined for monitoring the treatment response was evaluated.

The serum CEA level below $5 \mathrm{ng} / \mathrm{ml}$ and serum CA 19-9 level below $37 \mathrm{U} / \mathrm{ml}$ were considered as normal level for the present study.

\section{Inclusion Criteria}

\section{For Study Group}

1. Patients were identified as individuals suffering from oesophageal, gastric, and colon cancers currently diagnosed by endoscopic examination and biopsy and who have not previously received any anticancer therapy.

2. Patients who were willing to follow for at least 6 months after completion of treatment.

\section{For Control Group}

Patient were diagnosed as non- cancer cases of any site after initial examination and base line investigations.

\section{Exclusion Criteria}

\section{For Study Group}

1. Patients who were started and/or completed any form of treatment of gastrointestinal cancer.

2. Patients who were diagnosed and under treatment and/or completed treatment for cancer of any site.

\section{For Control Group}

1. Healthy subjects with any type of gastrointestinal infections, acute illness, recent hospitalization, or addiction to smoking, alcohol, or tobacco are excluded from this study.

2. Cancer patients who have received radiotherapy, chemotherapy or surgery were excluded.

3. Patient with strong family history of gastrointestinal cancer and any cancer.

A proforma for all the patients were maintained where a brief history, clinical information including age, sex, dietary habits, bowel habits, routine and radiological investigations like ultrasonography, CT Scan, MRCP and details of treatment like Surgery, Radiotherapy, Chemotherapy were clearly noted.

In the study group, blood samples were taken to estimate the levels of CEA and CA19-9, once before starting of treatment which may be Surgery, Radiotherapy or Chemotherapy. During the treatment, blood samples were taken at 6 weeks after the onset of treatment in case of Radiotherapy and at 12 weeks after start of Chemotherapy. Blood samples from undergoing either Radiotherapy or Chemotherapy were both taken again after 4 weeks after completion of treatment. In the control group, blood samples were taken only once for estimation of the levels of CEA and CA 19-9.

\section{Statistical Tools}

Data collected were entered in Microsoft Excel and later on transferred to SPSS v 22.0. Data analysis was done by using descriptive statistics as well as by applying Chi-square test and student's- test wherever needed. $\mathrm{P}$ value of $<0.005$ was taken a significance difference.

\section{RESULTS}

Among the 50 patients of study group, 58\% (29) were male and $42 \%$ (21) were female. In the control group number of male and female were $52 \%$ (26) and 48\% (24) respectively. In both the study group and control group males were more than female. (Table 1).

\begin{tabular}{|c|c|c|c|}
\hline Group & \multicolumn{2}{|c|}{ No. of Patients } & \multirow{2}{*}{ Total (\%) } \\
\hline & Male (\%) & Female (\%) & \\
\hline Study & $29(58.0)$ & $21(42.0)$ & $50(100)$ \\
\hline Control & $26(52.0)$ & $24(48.0)$ & $50(100)$ \\
\hline Total & $55(55.0)$ & $45(45.0)$ & 100 \\
\hline \multicolumn{4}{|c|}{ Table 1 Distribution of Study Group by Sex } \\
\hline
\end{tabular}

$\chi^{2}=0.364$ with 1 d.f; $p=0.546>0.05$, Not significant. 


\begin{tabular}{|c|c|c|c|c|c|}
\hline \multirow{2}{*}{ Group } & \multirow{2}{*}{ Number } & \multicolumn{3}{|c|}{ Mean Age } & \multirow{2}{*}{$\begin{array}{c}\text { Age } \\
\text { Range }\end{array}$} \\
\cline { 3 - 5 } & & Male & Female & Overall & $18-75$ \\
\hline Study & 50 & 50.47 & 54.33 & 52.08 & $18-76$ \\
\hline Control & 50 & 42.16 & 44.23 & 39.91 & $18-76$ \\
\hline
\end{tabular}

Table 2. Mean Age of Patients in Study and Control Groups

The overall mean ages of study and control group were 52.08 and 39.91 respectively. Mean age of males in the study and control group were 50.47 and 42.16 respectively. Female in the study group has mean age of 54.33 and that in control group has mean age of 44.23 .

\begin{tabular}{|c|c|c|c|}
\hline Age (years) & Study (\%) & Control (\%) & Total (\%) \\
\hline $10-29$ & $7(14 \%)$ & $10(20 \%)$ & $17(17 \%)$ \\
\hline $30-49$ & $7(14 \%)$ & $8(16 \%)$ & $15(15 \%)$ \\
\hline $50-69$ & $32(64 \%)$ & $30(60 \%)$ & $62(62 \%)$ \\
\hline 70 and above & $4(8 \%)$ & $2(4 \%)$ & $6(6 \%)$ \\
\hline Total & $\mathbf{5 0}(100 \%)$ & $\mathbf{5 0}(100 \%)$ & $\mathbf{1 0 0}$ \\
\hline Table 3. Distribution of Age among Study and Control \\
Groups \\
\hline
\end{tabular}

$\chi^{2}=1.327$ with 3 d.f; $p=0.723$, Not significance.

Age distribution as shown in Table 3. The age distribution of the study and the control groups were comparable, where the maximum number patient were in the age group of 50 to 69 years and above 70 years group has least numbers.

Table 4 shows the number of cases according the site of cancer. Maximum number of cancer occurred at the stomach followed by colon and minimum number of cancer in the caecum, anal canal and pancreas. 17 (34\%) cancer were found in stomach, $13(26 \%)$ in colon and $2(5 \%)$ each in caecum, anal canal and pancreas.

\begin{tabular}{|c|c|c|}
\hline Site & Number of Cases & Percentage \\
\hline Oesophagus & 3 & $6 \%$ \\
\hline Stomach & 17 & $34 \%$ \\
\hline Colon & 13 & $26 \%$ \\
\hline Caecum & 2 & $4 \%$ \\
\hline Rectum & 6 & $12 \%$ \\
\hline Anal Canal & 2 & $4 \%$ \\
\hline Gall Bladder & 5 & $10 \%$ \\
\hline Pancreas & 2 & $4 \%$ \\
\hline Total & 50 & 100 \\
\hline
\end{tabular}

\begin{tabular}{|c|c|c|c|}
\hline $\begin{array}{c}\text { Phases of } \\
\text { Analysis }\end{array}$ & $\begin{array}{c}\text { Male Mean } \pm \\
\text { SD of CEA }\end{array}$ & $\begin{array}{c}\text { Female Mean } \\
\mathbf{\pm S D} \text { of CEA }\end{array}$ & p-Value \\
\hline Pre-Treatment & $27.68 \pm 3.74$ & $41.45 \pm 6.11$ & 0.36 \\
\hline During Treatment & $27.24 \pm 5.19$ & $41.02 \pm 12.88$ & 0.34 \\
\hline Post Treatment & $47.75 \pm 5.84$ & $42.76 \pm 11.41$ & 0.80 \\
\hline \multicolumn{4}{|c|}{ Table 5. Sex Distribution of Mean of CEA $\mathbf{n g} / \mathbf{m L}$} \\
\hline
\end{tabular}

Table 5 shows that the mean CEA for male was 27.24( \pm 5.19) during treatment while $47.75( \pm 5.84)$ during post treatment. And the mean CEA for female was $41.02( \pm 12.88)$ during treatment while $42.76 \quad( \pm 11.41)$ during post treatment. There is no significant difference in the mean of CEA levels between males and females in all the three phases of analysis. ( $P>0.05)$ in each phases of analysis (By Applying Independent $\mathrm{T}$-test)

\begin{tabular}{|c|c|c|c|}
\hline $\begin{array}{c}\text { Phases of } \\
\text { Analysis }\end{array}$ & $\begin{array}{c}\text { Male Mean } \mathbf{4 S D} \\
\text { of CA 19-9 }\end{array}$ & $\begin{array}{c}\text { Female Mean } \\
\mathbf{\pm S D} \text { of CA 19-9 }\end{array}$ & p value \\
\hline Pre-treatment & $95.28 \pm 12.26$ & $117.09 \pm 16.321$ & 0.61 \\
\hline $\begin{array}{c}\text { During } \\
\text { Treatment }\end{array}$ & $83.62 \pm 12.88$ & $109.8 \pm 13.34$ & 0.49 \\
\hline Post treatment & $102.96 \pm 14.44$ & $114.07 \pm 14.62$ & 0.79 \\
\hline
\end{tabular}

Table 6. Sex Distribution of Mean CA19-9 U/mL

Table 6 also shows the mean CA 19-9 for male was 83.62 \pm 12.88$)$ during treatment while $102.96( \pm 14.44)$ during post treatment. And the mean CA 19-9 for female was $109.8( \pm 13.34)$ during treatment while $114.07( \pm 14.62)$ during post treatment. No significant difference in the mean CA 19-9 levels between males and females in the analysis. $(P>0.05)$ in each phases of analysis (By Applying Independent T-test)

\begin{tabular}{|c|c|c|c|c|}
\hline Parameters & \multicolumn{3}{|c|}{ Study Group } & Control \\
\hline \multirow{2}{*}{$\begin{array}{c}\text { Mean and SD } \\
\text { of CEA } \\
(\mathrm{ng} / \mathrm{ml})\end{array}$} & \begin{tabular}{c|} 
Pre- \\
Treatment
\end{tabular} & $\begin{array}{c}\text { During } \\
\text { Treatment }\end{array}$ & $\begin{array}{c}\text { Post } \\
\text { Treatment }\end{array}$ & \multirow[b]{2}{*}{$\begin{array}{c}3.36 \pm \\
1.64\end{array}$} \\
\hline & $\begin{array}{c}33.46 \pm \\
4.01\end{array}$ & $\begin{array}{c}33.03 \pm \\
9.35\end{array}$ & $\begin{array}{c}45.66 \pm \\
17.25\end{array}$ & \\
\hline P-Value & 0.00001 & 0.00001 & 0.0036 & \\
\hline
\end{tabular}

Table 7. Mean CEA Values for Study and Control Groups

From the above table shows that the mean and SD of CEA for study group in pre- treatment, during treatment and post treatment phases are $33.46 \pm 4.01,33.03 \pm 9.35$ and $15.73 \pm 11.5$ respectively. The mean and SD of control group is $3.36 \pm 1.64$. We can be concluded that there is highly significant difference of CEA levels between study and control group $(\mathrm{P}<0.05)$ in all the three phases of analysis i.e. pretreatment, during treatment and post treatment.

\begin{tabular}{|c|c|c|c|c|}
\hline Parameters & \multicolumn{3}{|c|}{ Study Group } & Control \\
\hline & $\begin{array}{c}\text { Pre- } \\
\text { Mean and SD }\end{array}$ & $\begin{array}{c}\text { During } \\
\text { treatment }\end{array}$ & $\begin{array}{c}\text { Post } \\
\text { treatment }\end{array}$ & \\
\cline { 2 - 4 } treatment CA 19-9 & $104.44 \pm$ & $94.62 \pm$ & $107.63 \pm$ & $15.73 \pm$ \\
(units/ml) & 14.29 & 13.08 & 14.53 & 11.5 \\
\hline P- Value & 0.00001 & 0.0018 & 0.00660 & \\
\hline
\end{tabular}

Table 8. Mean CA 19-9 Values for Study and Control Groups

The above table shows that the mean and SD of CA 19-9 for study group in pre- treatment, during treatment and post treatment phases are 104.44 $\pm 14.29,94.62 \pm 13.08$ and $107.63 \pm 14.53$ respectively. The mean and SD of CA 19-9 for control group is $15.73 \pm 11.5$. It can be concluded from the above table that there is highly significant difference of mean CA 19-9 between study and control groups in all the three phases of analysis $(\mathrm{P}<0.05)$.

\section{DISCUSSION}

The mean values of pre-treatment CEA was $34 \mathrm{ng} / \mathrm{ml}$ (5.5 ng/ml- $202 \mathrm{ng} / \mathrm{ml}$ ) as shown by Yamao T et al 19992. The present study also shows pre-treatment CEA value of 33.46 $\mathrm{ng} / \mathrm{ml}$ (range being $2.5 \mathrm{ng}-185 \mathrm{ng} / \mathrm{ml}$ ) as show in table 7 . Ishizuka D et al $2001^{10}$ also showed that Serum CEA levels before treatment to be $33.2 \mathrm{ng} / \mathrm{ml}$ (2 ng-433 ng/ml). Wiratkapun et al $2001^{5}$ also found the mean CEA to be $35 \mathrm{ng} / \mathrm{ml}$ (range being 5-496 $\mathrm{ng} / \mathrm{ml}$ ).Some authors were of the opinion that the use of adjuvant chemotherapy and radiotherapy is of no benefit in patients who have elevated levels of CEA and CA 19-9 prior to treatment (Behbehani AI et 
al 2000).11 It is observed that the post treatment values were higher than pre-treatment values although the values during treatment were lower than pre-treatment, indicating initial treatment response. The higher post treatment values may be because there is no effective response to treatment or there may be recurrence or metastasis as most of the cases under the current study were in advanced stage of the disease having high levels of these markers. Gastrointestinal cancer patients with higher CEA levels were significantly more common among male patients $(\mathrm{p}<0.05)$ a propensity not observed with CA 19-9 (Kim DY et al 2000,12 Nakane Y et al 199413). The present study in the contrary shows that there is no statically significant difference between male and female patients in all the three phases of analysis ( $\mathrm{P}$ value $>0.34$ ) The present study also shows that either CEA alone or CA19-9 alone is not useful in diagnosis of gastrointestinal cancers but combined study of these markers may be useful. The observation is in agreement with that of many previous studies (Thomas WM et al 1991,14 Carpelan HM et al 2002.15) Sears HF et al $1982^{16}$ reported detection of CA19-9 in a significant number of patients who were negative for CEA, so also, a number of patients with elevated CEA levels did not show elevated CA 19-9 measurement (Naritmatsu $\mathrm{H}$ et al 1996). ${ }^{17}$

\section{CONCLUSION}

The highest prevalence of gastrointestinal cancers is seen in the age group of 50-69 years. Males outnumber the females. The mean value of CEA and CA19-9 were much higher in patients of gastrointestinal cancers. There is no difference between mean CEA and CA19-9 between males and females. CEA alone may not be very useful marker for diagnosis of gastrointestinal cancers but if evaluated with CA19-9 its usefulness is increased manifold. CEA and CA19-9 can be a useful marker for monitoring of treatment response and predicting prognosis in gastrointestinal tumours. Further more, if follow-up of the cases can be done annually, assessment of prognosis of the patients will be more accurate.

\section{ACKNOWLEDGEMENT}

Authors would like to thank Mrs Minita Ningombam, Assistant Professor of Biostatistics, Department of Community Medicine, JNIMS, Imphal for supporting in statistical analysis in our study.

\section{REFERENCES}

[1] Park K. Cancer. Park's Textbook of Preventive and social medicine. 20th edn. Jabalpur, India: M/S Banarasidas Bhanot Publishers 2000: p. 283-5.

[2] Yamao T, Kai S, Kazami A, et al. Tumour markers CEA, CA 19-9 and CA 125 in monitoring of response to systemic chemotherapy in patients with advanced gastric cancer. Jpn J Clin Oncol 1999;29(11):550-5.

[3] Gold P, Freedman So. Demonstration of tumourspecific antigens in human colonic carcinoma by immunological tolerance and absorption techniques, J Exp Med 1965;121:439-62.
[4] Sherret GV. The Epigenetics of tumour malignancy, the biology of tumour malignancy. USA: Academic Press Inc., 1982: p. 115-9.

[5] Wiratkapun S, Kroemer M, Seow - Choen F, et al. High preoperative serum carcinoembryonic antigen predicts metastatic recurrence in potentially curative colonic cancer: results of a five year study. Dis Colon Rectum 2001;44(2):231-5.

[6] Posner MR, Mayer RJ. The use of serologic tumour markers in gastrointestinal malignancies. Hematology Oncology Clinics of North America 1994;8(3):533-53.

[7] Koprowski H, Steplewski Z, Mitchell K. Colorectal carcinoma antigens detected by hybridoma antibodies. Somatic Cell Genet 1979;5(6):957-71.

[8] James TW. Diagnosis and management of cancer using serological tumour markers, clinical diagnosis and management by laboratory method: John Bernard Henry. 19th edn. Philadelphia: WB Saunders Company 1996: p. 1064-76.

[9] Ueda T, Shimada E, Urakawa T. The clinicopathologic features of serum CA 19-9 positive colorectal cancers. Surg Today 1994;24(6):518-25.

[10] Ishizuka D, Shirai Y, Sakai Y, et al. Colorectal carcinoma liver metastases: clinical significance of preoperative measurement of serum carcinoembryonic antigen and carbohydrate antigen 19-9 levels. Int J Colorectal Dis 2001;16(1):32-7.

[11] Behbehani AI, AI-Sayer H, Farghaly M, et al. Prognostic significance of CEA and CA 19-9 in colorectal cancer in Kuwait. Int J Biol Markers 2000;15(1):51-5.

[12] Kim DY, Kim HR, Shim JH, et al. Significance of serum and tissue carcinoembryonic antigen for the prognosis of gastric carcinoma patients. J Surg Oncol 2000;74(3):185-92.

[13] Nakane Y, Okamura S, Akahira K, et al. Correlation of preoperative carcinoembryonic antigen levels and prognosis of gastric cancer patients. Cancer 1994;73(11):2703-8.

[14] Thomas WM, Robertson JFR, Price MR, et al. Failure of CA 19-9 To detect asymptomatic colorectal carcinoma. Br J Cancer 1991;63(6):975-6.

[15] Carpelan-Holmstrom M, Louhinmo J, Stenman UH, et al. CEA, CA 19-9 and CA 72-4 improve the diagnostic accuracy in gastrointestinal cancers. Anticancer Res 2002;22(4):2311-6.

[16] Sears HF, Herlyn M, Del Veliano B, et al. Monoclonal antibody detection of a circulating tumour associated antigen. II. A longitudinal evaluation of patients with colorectal cancer. J Clin Immunol 1982;2(2):141-9.

[17] Naritmatsu H, Iwasaki H, Nishihara S, et al. Genetic evidence for the Lewis enzyme, which synthesizes type-1 Lewis antigens in colon tissue and intracellular localization of the enzyme. Cancer Res 1996;56(2):330-8. 